\title{
Detección de anticuerpos contra diarrea viral bovina en cabras de cuatro provincias de Lima, Perú
}

\author{
Detection of antibodies against bovine viral diarrhoea virus in goats of four \\ provinces of Lima, Peru
}

\author{
Diana Benito F. ${ }^{1}$, Hermelinda Rivera G. ${ }^{1,2}$, Ana Castillo E. ${ }^{1}$, Dennis Navarro M. ${ }^{1}$, \\ Angel Gómez M. ${ }^{1}$
}

\section{Resumen}

El objetivo del presente estudio fue determinar anticuerpos contra el virus de la diarrea viral bovina (VDVB) en muestras de suero de caprinos adultos, hembras y machos, de crianza estabulada, semi-extensiva y trashumante, pertenecientes a 89 criadores de cuatro provincias del departamento de Lima: Huaura $(n=196)$, Huaral $(n=233)$, Canta $(n=153)$ y Lima $(n=172)$. La detección de los anticuerpos neutralizantes contra el VDVB en muestras de suero $(n=754)$ se hizo mediante la prueba de neutralización viral. El 1.2\% $(9 / 754)$ de las muestras presentaron anticuerpos contra el VDVB. Las muestras serorreactoras fueron de cabras de crianza trashumante de las provincias de Canta y Huaura.

Palabras clave: caprinos; pestivirus; diarrea viral bovina; anticuerpos; neutralización viral

\section{Abstract}

The aim of this study was to determine antibodies against the bovine viral diarrhea virus (BVDv) in serum samples of adult goats, females and males, of intensive, semiextensive and transhumant production systems, from 89 farmers of four provinces of the department of Lima: Huaura $(n=196)$, Huaral $(n=233)$, Canta $(n=153)$ and Lima $(n=172)$. The detection of neutralizing antibodies against the BVDv in serum samples $(n=754)$ was done by the viral neutralization test. The results showed that $1.2 \%(9 / 754)$ of the samples had antibodies against the virus. Seroreactive samples were from transhumant goats from the provinces of Canta and Huaura.

Key words: goats; pestivirus; bovine viral diarrhoea virus; antibodies; viral neutralization test

\footnotetext{
${ }^{1}$ Laboratorio de Microbiología y Parasitología Veterinaria, Facultad de Medicina Veterinaria, Universidad Nacional Mayor de San Marcos, Lima, Perú

${ }^{2}$ E-mail: hriverag@unmsm.edu.pe
}

Recibido: 16 de enero de 2018

Aceptado para publicación: 3 de agosto de 2018 


\section{INTRODUCCIÓN}

La población caprina del Perú es de 1928000 cabezas distribuidas en todo el país, pero con predominancia en los departamentos de Piura, Ancash, Ayacucho y Lima (INEI, 2012). La crianza caprina es una actividad ganadera que cumple un rol socioeconómico de importancia en la población rural; siendo en la mayoría de los casos, el principal sustento para numerosas familias de escasos recursos económicos (Arrollo, 2007; Mahmoud Abdel Aziz, 2010).

La crianza caprina en el Perú es mayormente de tipo extensiva y de trashumancia, pero además, se tienen rebaños bajo crianza semi-extensiva y estabulada. En el primer caso, los animales son desplazados entre la costa y la sierra para el aprovechamiento de las pasturas naturales, rastrojos, subproductos de la agricultura y ramoneos de arbustos, y no poseen controles sanitarios ni reciben asistencia técnica. En caso de la crianza semiextensiva es similar, pero los animales reciben un suplemente alimenticio en sus corrales de descanso. La crianza estabulada comprende a pocos hatos ubicados principalmente en la costa y cuentan con buen sistema de manejo y control sanitario (Arroyo, 1998, 2007).

Los caprinos domésticos y silvestres son susceptibles a muchas enfermedades infecciosas y parasitarias, sobre todo cuando comparten las áreas de pastoreo (Falconi et al., 2010). En el Perú, los caprinos criados en forma trashumante y semiextensiva conviven con bovinos y ovinos, favoreciendo la transmisión inter-especie de brucelosis (Toledo et al., 2007), paratuberculosis (observación clínica no publicada) y posiblemente infecciones virales como la diarrea viral bovina y la enfermedad de la frontera, causados por virus que pertenecen al género Pestivirus de la familia Flaviviridae (Passler et al., 2014).

El género pestivirus comprende tres especies: el virus de la diarrea viral bovina-
(VDVB) que afecta principalmente al bovino, el virus de la enfermedad de la frontera (VEF), observado en el ovino y caprino ( $\mathrm{Li}$ et al., 2013) y el virus de la peste porcina clásica, que afecta al porcino (Meyers y Thiel, 1996). El VDVB y el VEF son genética y antigénicamente relacionados, por lo que los anticuerpos no son diferenciables por pruebas convencionales como ELISA indirecta o neutralización viral (Becher et al., 2003).

El virus de la DVB está ampliamente distribuido en bovinos y rumiantes silvestres del mundo (Passler et al., 2016) afectando los tejidos reproductivos (Grooms, 2004; Givens y Marley, 2008) respiratorios (Ridpath, 2010) y al sistema inmune (Chase, 2013). A diferencia, el VEF es mayormente descrito en ovinos y caprinos ocasionando infecciones subclínicas o agudas similares a los ocasionados por el VDVB (Li et al., 2013; Bachofen et al., 2013), aunque su prevalencia en cabras es variable, reportándose entre 2 a $25 \%$ e incluso hasta 50\% (Løken., 1990; Mishra et al., 2009; Al-Rubayie et al., 2014).

En VDVB esta difundido en el país en la población bovina, ovina y camélidos sudamericanos del país (Alvarez et al., 2002; Flores et al., 2010). Los bovinos pueden presentar infecciones subclínicas o agudas con ligera fiebre, abortos, infertilidad temporal y es parte del complejo respiratorio bovino (Rivera, 2001). En un estudio serológico en ovejas con problemas reproductivos se encontró $69.5 \%$ de reactores contra el VDVB (Flores et al., 2010); sin embargo, la asociación de la seropositividad a los pestivirus con los problemas reproductivos en ovejas requiere de más estudios.

Pese a la importancia de la especie caprina, los criadores solo cuentan con escasos programas sanitarios oficiales aparte de la brucelosis caprina. No existen reportes de infección por pestivirus en la población caprina del país, por lo que el objetivo del presente estudio fue detectar anticuerpos contra el VDVB en caprinos criados en forma tras- 
humante, semiextensiva y estabulada en las provincias de Huaura, Huaral, Canta y Lima del departamento de Lima.

\section{Materiales y Métodos}

El estudio fue realizado con muestras de sueros de caprinos hembras y machos adultos colectadas durante el monitoreo de brucelosis realizado por personal del Servicio Nacional de Sanidad Agraria (SENASA) en 2011 y 2012. Las muestras fueron obtenidas de rebaños o hatos caprinos de 89 criadores de la modalidad trashumante ( $\mathrm{n}=40$ rebaños), semiextensiva ( $\mathrm{n}=46$ rebaños) y estabulada ( $n=3$ hatos) (Cuadro 1). Las cabras eran mayormente criollas, pero también habían de las razas Saanen, Alpina, Anglo-Nubian y sus cruces.

La población caprina estuvo distribuida en seis distritos de cuatro provincias del departamento de Lima: Sayán $(n=3562)$ y Huaura $(n=2607)$ en la provincia de Huaura, Huaral $(n=1253)$ y Aucallama $(n=1053)$ en la provincia de Huaral, Santa Rosa de Quives $(n=1661)$ en la provincia de Canta, y San Pedro de Carabayllo $(n=5038)$ en la provincia de Lima (Cuadro 2). Del total de muestras disponibles, se seleccionaron 754 muestras en base a un muestreo por conveniencia, considerando animales entre mayores a 6 meses y 6 años de edad, de ambos sexos, y que fueran de diferentes rebaños y procedencia.

Se utilizaron monocapas de cultivo de células secundarias de cornete nasal de feto bovino (CNB) preparados en el Laboratorio de Virología de la Facultad de Medicina Veterinaria (FMV) de la Universidad Nacional Mayor de San Marcos (UNMSM). Así mismo, medio de cultivo MEM (Minimum Essential Medium), suero fetal bovino libre de virus DVB (Sigma, EEUU) y sueros controles de referencia positivo y negativos. La cepa VDVB presentaba un título de $10^{-5}$ $\mathrm{DI}_{50} \mathrm{CC} / 50 \mu \mathrm{l}$.
La detección de los anticuerpos contra el virus de la DVB se realizó mediante la prueba de virus neutralización según el protocolo disponible en el Laboratorio de Virología de la FMV, UNMSM, descrito en el Manual de la OIE (2017). Una muestra de suero fue considerada positiva a anticuerpos contra el VDVB al neutralizar el $100 \%$ de la capacidad infectante del virus en cultivo celular, manifestado por ausencia del efecto citopático, y negativo si no neutraliza la capacidad infectante del virus, observándose el efecto citopático en las monocapas de células. Los sueros con títulos iguales o mayores a 1:4 fueron considerados positivos a anticuerpos contra VDVB.

\section{Resultados y Discusión}

El 1.2\% (9/754) de las muestras de las cabras presentaron anticuerpos contra el VDVB. De las nueve muestras seropositivas, tres fueron detectadas en un rebaño de Sta. Rosa de Quives, cuatro fueron detectados en dos rebaños de Huaura y dos en un rebaño de Sayán (Cuadro 3). Los anticuerpos fueron detectados en cabras hembras de 3 a 6 años con títulos de 8 a 128 (Cuadro 4).

En el país, la DVB está asociada al sistema de manejo, tamaño de la población, presencia de animales portadores del virus, tipo de crianza intensiva o extensiva (Ridpath, 2010). Sin embargo, no se dispone de estudios previos de prevalencia del virus de la DVB en la población caprina del país, lo cual podría ser debido al tipo de crianza, que en su mayoría es trashumante y semi-extensiva, lo cual dificulta el muestreo. La prevalencia del VDVB en cabras en otros países es variable; por ejemplo, se reportan prevalencias entre 2 y $25 \%$ en Suiza (Bachofen et al., 2013), 16.9\% en India (Mishra et al., 2009), $6.5 \%$ en Chile (Celedón et al., 2001), y 4.1\% en Corea del Sur (Yang et al., 2008). 
Cuadro 1. Lugar, tipo de crianza y número de criadores de cabras del departamento de Lima, Perú, distribuidos por distritos

\begin{tabular}{lcccc}
\hline \multirow{2}{*}{ Distrito } & \multicolumn{3}{c}{ Tipo de crianza } & \multirow{2}{*}{ Total } \\
\cline { 2 - 4 } & Estabulada & Semiextensiva & Trashumante & \\
\hline Sayán & 0 & 5 & 12 & 17 \\
Huaura & 0 & 10 & 8 & 18 \\
Huaral & 0 & 2 & 4 & 6 \\
Aucallama & 0 & 3 & 3 & 6 \\
Santa Rosa de Quives & 0 & 11 & 10 & 21 \\
San Pedro de Carabayllo & 3 & 11 & 10 & 21 \\
\hline Total & 3 & 46 & 40 & 89 \\
\hline
\end{tabular}

Cuadro 2. Procedencia, población de caprinos, número de criadores y número de muestras incluidas en el estudio por distritos de las cuatro provincias del departamento de Lima

\begin{tabular}{|c|c|c|c|c|c|c|}
\hline \multirow[b]{2}{*}{ Provincia } & \multirow[b]{2}{*}{ Distrito } & \multirow[b]{2}{*}{$\begin{array}{l}\text { Población } \\
\text { caprina (n) }\end{array}$} & \multirow[b]{2}{*}{$\begin{array}{l}\text { Criadores } \\
\text { (n) }\end{array}$} & \multirow[b]{2}{*}{$\begin{array}{l}\text { Muestras } \\
\text { (n) }\end{array}$} & \multicolumn{2}{|c|}{ Sexo } \\
\hline & & & & & $\begin{array}{c}\text { Hembra } \\
(\mathrm{n})\end{array}$ & $\begin{array}{l}\text { Macho } \\
\text { (n) }\end{array}$ \\
\hline \multirow[t]{2}{*}{ Huara } & Sayán & 3562 & 17 & 108 & 108 & 0 \\
\hline & Huara & 2607 & 18 & 87 & 86 & 1 \\
\hline \multirow[t]{2}{*}{ Huaral } & Huaral & 1253 & 6 & 180 & 171 & 9 \\
\hline & Aucallama & 1053 & 6 & 54 & 46 & 8 \\
\hline Canta & $\begin{array}{l}\text { Sta. Rosa de } \\
\text { Quives }\end{array}$ & 1661 & 21 & 153 & 140 & 13 \\
\hline Lima & Carabayllo & 5038 & 21 & 172 & 147 & 25 \\
\hline Total & & 15,174 & 89 & 754 & 698 & 56 \\
\hline
\end{tabular}

Cuadro 3. Presencia de anticuerpos neutralizantes contra diarrea viral bovina en cabras (machos y hembras) de seis distritos de Lima

\begin{tabular}{lcc}
\hline Distrito & $\begin{array}{c}\text { Caprinos } \\
(\mathrm{n})\end{array}$ & $\begin{array}{c}\text { Seropositivos } \\
(\%)\end{array}$ \\
\hline Sta. Rosa de & 153 & 1.9 \\
Quives & 54 & 0 \\
Aucallama & 179 & 0 \\
Huaral & 87 & 2.3 \\
Huaura & 109 & 3.6 \\
Sayán & 172 & 0.0 \\
Carabayllo & 754 & 1.2 \\
\hline Total & 754 \\
\hline
\end{tabular}

Es importante indicar que los anticuerpos contra el VDVB encontrados en los sueros de cabras podrían haber sido inducidos por este virus o por el virus de la enfermedad de la frontera (VEF), ya que los dos pestivirus comparten estructura antigénica (Sullivan et al., 1994; Paton et al., 1997), de modo que los anticuerpos neutralizantes no pueden ser diferenciados por la prueba de neutralización viral, sobre todo en títulos bajos. Está descrito que el VDVB afecta principalmente al bovino y el VEF al ovino, pero ambos virus pueden afectar a los caprinos (Løken, 2000; Pratelli et al., 2001; Scherer et al., 2001; Swasdipan et al., 2001). Es así que, ante la estrecha relación antigénica en- 
Cuadro 4. Título de anticuerpos contra el virus de la diarrea viral bovina (VDVB) detectados en cabras seropositivas a anticuerpos contra el VDVB

\begin{tabular}{cccccc}
\hline $\begin{array}{c}\text { Rango de título de } \\
\text { anticuerpos contra DVB } \\
\text { (inversa de la dilución) }\end{array}$ & Canta & Huaral & Huaura & Lima & Total \\
\hline 4 a 8 & 1 & 0 & 2 & 0 & 3 \\
16 a 64 & 1 & 0 & 3 & 0 & 4 \\
128 a 256 & 1 & 0 & 1 & 0 & 2 \\
\hline Total & 3 & 0 & 6 & 0 & 9 \\
\hline
\end{tabular}

tre los dos virus, es que ambos pueden ser usados para identificar anticuerpos contra pestivirus en cabras u ovinos. En este estudio se utilizó la cepa Singer del VDVB como antígeno viral.

La baja frecuencia (1.2\%) de cabras seropositivas criadas en las cuatro provincias de Lima sugiere la existencia de factores que disminuyen la transmisibilidad viral hacia los caprinos. Uno de estos factores podría ser la ausencia o escasa presencia de animales portadores del virus. Por ejemplo, en Austria solo se ha detectado $0.08 \%$ de animales portadores (Krametter-Froetscher et al., 2010), posiblemente debido a que las cabras infectadas por el VDVB abortan o las crías nacen muertas o mueren poco después de nacer (Løken et al., 1991).

Los anticuerpos neutralizantes fueron detectados en cabras de 3-6 años de crianza trashumante y tuvieron un rango de 1:8 a 1:128 (Cuadro 4), indicando que fueron anticuerpos específicos contra el VDVB de campo. Si bien el contacto con bovinos durante el pastoreo no era frecuente, los criadores manifestaron que algunos propietarios de los fundos agrícolas de la zona tienen 3 a 5 vacas que pudieron estar en contacto con las cabras, pues la prevalencia del VDVB en hatos lecheros es entre 40 y $>50 \%$
(Aguilar et al., 2006; Huamán et al., 2007). En el presente estudio no se pudo esclarecer el momento de la infección, pero los anticuerpos inducidos por un pestivirus son catabolizados en forma lenta, pudiendo persistir por toda la vida del animal (Fredriksen et al., 1999). Según los dueños de los rebaños que tuvieron animales reactores al virus indicaron que los animales seropositivos nacieron dentro del rebaño, por lo que en algún momento habrían sido infectados al compartir pasturas con hatos bovinos infectados, sobre todo en zonas como Santa Rosa de Quives.

\section{Conclusión}

El virus de la diarrea viral bovina no está ampliamente difundido en cabras de crianza trashumante, semiextensiva y estabulada en cuatro provincias del Departamento de Lima.

\section{Literatura Citada}

1. Aguilar R, Benito A, Rivera H. 2006. Seroprevalencia del virus de la diarrea viral bovina en ganado lechero de crianza intensiva del valle de Lima. Rev Inv Vet Perú 17: 148-153. doi: http:// dx.doi.org/10.15381/rivep.v17i2.1530 
2. Al-Rubayie KMI, Hasso SA. 2014. Detection of border disease in ovine using ELISA in Iraq. Int J Curr Microbiol App Sci 3: 1051-1055.

3. Álvarez S, Rivera H, Pezo D, Rosadio R. 2001. Diarrea viral bovina en rumiantes de una comunidad campesina de la provincia de Canchis, Cusco. Rev Inv Vet Perú 13: 46-51. doi: http://dx.doi.org/ 10.15381/rivep.v13i1.1705

4. Arroyo O. 1998. Producción de caprinos. Lima: PROCABRA. 399 p.

5. Arroyo O. 2007. Situación actual y proyecciones de la crianza de caprinos en el Perú. Arch Latinoam Prod Anim 15: 290-293.

6. Bachofen C, Vogt H, Stalder H, Mathys T, Zanoni $R$, Hilbe $M$, Schweizer M, et al. 2013. Persistent infections after natural transmission of bovine viral diarrhoea virus from cattle to goats and among goats. Vet Res 44: 32. doi: 10.1186/1297-9716-44-32

7. Becher P, Ramirez, R, Orlich, M, Rosales SC, König, M, Schweizer M, Stalder $H$, et al. 2003. Genetic and antigenic characterization of novel pestivirus genotypes: implications for classification. Virology 311: 96-104. doi: 10.1016/S0042-6822(03)00192-2

8. Celedón M, Sandoval A, Droguett J, Calfio R, Ascencio L, Pizarro-Lucero $J$, Navarro C. 2001. Pesquisa de anticuerpos seroneutralizantes para pestivirus y herpesvirus en ovinos, caprinos y camélidos sudamericanos de Chile. Arch Med Vet 33: 165-172. doi: 10.4067/S0301-732X2001000200005

9. Chase CL. 2013. The impact of BVDV infection on adaptive immunity. Biologicals 41: 52-60. doi: 10.1016/ j.biologicals.2012.09.009

10. Falconi C, Oleaga A, López-Olvera JR, Casais R, Prieto M, Gortázar Ch. 2010. Prevalence of antibodies against selected agents shared between Cantabrian Chamois (Rupicapra pyrenaica parva) and domestic goats. Eur J Wildlife Res 52: 319-325. doi: 10.1007/s10344-009-0322-Z
11. Flores D, Rivera H, Gavidia C, Manchego A. 2010. Anticuerpos contra el virus de la diarrea viral bovina y su asociación con problemas reproductivos en borregas de una empresa ovejera de la sierra central del Perú. Rev Inv Vet Perú 21: 113-118. doi: 10.15381/rivep.v21i1.-363

12. Fredriksen B, Sandvik T, Loken T, Odegaard $S A$. 1999. Level and duration of serum antibodies in cattle infected experimentally and naturally with bovine virus diarrhoea virus. Vet Rec 144: 111- 114

13. Givens MD, Marley MSD. 2008. Infectious causes of embryonic and fetal mortality. Theriogenology 70:270-285. doi: 10.1016/j.theriogenology.2008.04.018

14. Grooms DL. 2004. Reproductive consequences of infection with bovine viral diarrhea virus. Vet Clin NAm-Food A 20: 5-19. doi: 10.1016/j.cvfa.2003.11.006

15. Huamán JC, Rivera H, Arainga M, Gavidia C, Manchego A. 2007. Diarrea viral bovina y animales portadores del virus en hatos productores de leche de la Irrigación de Majes, Arequipa. Rev Inv Vet Perú 18: 141-149. doi: 10.15381/ rivep.v18i2.1290

16. [INEI] Instituto Nacional de Estadística e Informática. 2012. IV Censo Nacional Agropecuario 2012. [Internet]. Disponible en: http://censos.inei.gob.pe/ cenagro/tabulados/

17. Krametter-Froetscher R, Duenser M, Preyler B, Theiner A, Benetka V, Moestl K, Baumgartner W. 2010. Pestivirus infection in sheep and goats in West Austria. Vet J 186: 342-346. doi: 10.1016/j.tvj1.2009.09.006

18. Li W, Mao L, Zao Y, Sun Y, He K, Jiang J. 2013. Detection of border disease virus (BDV) in goat herds suffering of diarrhea in eastern China. Virol J 10: 80. doi: 10.1186/1743-422X10-80

19. Loken T. 1990. Pestivirus infections in Norway. Epidemiological studies in goats. J Comp Pathol 103: 1-10. doi: 10.1016/S0021-9975(08)80130-2 
20. Loken T. 2000. Border disease in goats. In: Tempesta M (ed). Recent advances in goat diseases. Ithaca NY: International Veterinary Information Service. $p$ 120-145.

21. Loken T, Krogsrud J, Bjerkås I. 1991. Outbreaks of border disease in goats induced by a pestivirus-contaminated of vaccine, with virus transmission to sheep and cattle. J Comp Pathol 104: 195-209. doi: 10.1016/S0021-9975(08)80103-X

22. Mahmoud AA. 2010. Present status of the world goat population and their productivity. Lohmann Information 45: 42-52.

23. Meyers G, Thiel HJ. 1996. Molecular characterization of pestiviruses. Adv Virus Res 47: 53-118.

24. Mishra R, Rajukumar K, Tiwari A, Nema RK, Behera SP, Satav JS, Dubey SC. 2009. Prevalence of bovine viral diarrhoea virus (BVDV) antibodies among sheep and goats in India. Trop Anim Health Pro 41: 1231-1239. doi: 10.1007/s11250-009-9305-z

25. [OIE] Organización Mundial de Sanidad Animal. 2017. Manual de las pruebas de diagnóstico y de las vacunas para los animales terrestres 2017. [Internet]. Disponible en: http:// www.oie.int/es/normas-internacionales/ manual-terrestre/acceso-en-linea/

26. Passler T, Riddell KP, Edmonson MA, Chamorro MF, Neill JD, Brodersen $B W$, Walz H, et al. 2014. Experimental infection of pregnant goat with bovine viral diarrhea virus (BVDV) 1 or 2 . Vet Res 45: 38. doi: 10.1186/1297-9716-45-38.

27. Passler T, Ditchkoff SS, Wals PH. 2016. Bovine viral diarrhea virus (BVDV) in white-tailed deer (Odocoileus virginianus). Front Microbiol 7: 945. doi: $103389 /$ fmicb.2016.00495

28. Paton D, Gunn M, Sands J, Yapp F, Drew T, Vilcek S, Edwards S. 1997. Establishment of serial persistent infections with bovine viral diarrhoea virus in cattle and sheep and changes in epitope expression related to host species. Arch Virol 142: 929-938. doi: 10.1007/s007050050129

29. Pratelli A, Martella V, Cirone F, Buonavoglia D, Elia G, Tempesta M, Buonavoglia C. 2001. Genomic characterization of pestiviruses isolated from lambs and kids in southern Italy. J Virol Methods 94: 81-85. doi: 10.1016/ S0166-0934(01)00277-4

30. Ridpath J. 2010. Bovine viral diarrhea virus: global status. Vet Clin NAm-Food A 26: 105-121. doi: 10.1016/j.cvfa.2009.10.007

31. Rivera H. 2001. Causas frecuentes del aborto bovino. Rev Inv Vet Perú 12: 117 122.

32. Scherer CF, Flores EF, Weiblen R, Caron L, Irigoyen LF, Neves JP, Maciel MN. 2001. Experimental infection of pregnant ewes with bovine viral diarrhea virus type-2 (BVDV-2): effects of the pregnancy and fetus. Vet Microbiol 79: 285-299. doi: 10.1016/ S0378-1135(00)00357-6

33. Sullivan DG, Chang GJ, Trent DW, Akkina RK. 1994. Nucleotide sequence analysis of the structural gene coding region of the pestivirus border disease virus. Virus Res 33: 219-228. doi: 10.1016/0168-1702(94)90104-X

34. Swasdipan S, Bielefeldt-Ohmann $H$, Phillips N, Kirkland PD, Mcgowan MR. 2001. Rapid transplacental infection with bovine pestivirus following intranasal inoculation of ewes in early pregnancy. Vet Pathol 38: 275-280. doi: 10.1354/vp.38-3-275

35. Toledo M, Delgado A, Suarez F, Noé N. 2007. Prevalencia de brucelosis caprina en tres distritos de la provincia de Cañete, Lima. Rev Inv Vet Perú 18: 136-140. doi: 10.15381/rivep.v18i2.1289

36. Yang DK, Kweon CH, Kim BH, Choi CU, Kang MI, Hyun BH, Hwang IJ, et al. 2008. Prevalence and genotypes of pestivirus in Korean goats. Kor J Vet Res 48: 83-88. 